\title{
Hareketli Durağanlık İzlenimi: Bir Zamanlar Anadolu'da
}

\author{
Dilek TUNALI *
}

Özet

Nuri Bilge Ceylan’ın son filmi ‘Bir Zamanlar Anadolu'da’, yönetmenin filmografisinde hem radikal bir kopuşu hem de diḡer filmleriyle içten içe devam eden, aktarılan ve dönüştürülen eski bağları düşündürmektedir. Yönetmenin daha önceki yapımlarında fotoğrafik etkinin, görsel kompozisyonların ve biçimsel estetiğin ön plana çıkması, son filmi ile birlikte daha sağlam, katmanlı ve okunabilir bir yapıt olma özelliğini pekiştirmiştir. Açık formun bu kez salt filmin biçimsel çözümlemesini değil, daha da ötesine geçerek kültürel, toplumsal ve psikolojik olguların okunmasına izin veren (hatta bunu zorunlu kılan) bir yapıda olduğu görülmektedir. Film böylece toplum, kültür ve birey üzerinden, hem birbiriyle bağdaşan hem de tezatlıklar kuran, okunmaya açık durumlar yaratabilmektedir. Sıradan bir döngü içinde Bakhtinci anlamda 'diyalojikleşebilen' ve Bergsoncu anlamda 'durağanlık izlenimi üzerinden imge yaratabilen' yapısıyla, söylemsel ve felsefi bir içerik zemini oluşturabilmektedir.

Anahtar Sözcükler: Nuri Bilge Ceylan, Anadolu, Hiyerarşi, Imge-zaman, Diyaloji, Nevroz.

\section{Impression of Movement within Stability: Once Upon a Time in Anatolia}

\begin{abstract}
The last film of Nuri Bilge Ceylan titled 'Once Upon a Time in Anatolia' is a radical rupture in the filmography of the director and also could be considered within the context of previous links which are secretly treated, transferred and transformed. Distinguished features of photographic effect, visual compositions and formal aesthetics used in director's previous films reinforced its stability and hermeneutical readability with his last film. In this instance, it is observed that the open form not only allows to make a structural analysis of the film, but also makes it possible - even it necessitates - to read cultural, social and psychological facts. Thereby the film which makes the critical approach readable by its nature could create situations which can both accord and disaccord with each other through society, culture and individual. In a routine, it generates a hermeneutical, philosophical and contextual base which can be 'dialogical' in Bakhtinian sense and which can create 'image impression' through stability in Bergsonian sense.
\end{abstract}

Keywords: Nuri Bilge Ceylan, Anatolia, Chronotope, Image-time, Dialogic, Psychoneurosis. 


\section{Giriş}

Nuri Bilge Ceylan'ın 2011 yapımı son filmi 'Bir Zamanlar Anadolu'da', yönetmenin diğer filmleriyle karşılaştırıldığında belirgin bir kopuşu işaret eder. Yönetmenin önceki yapımlarında, fotografik estetiği ön planda tutarak öykü, karakter ve anlatı eksenini kırdığı ve böylece olguları araç haline getirmiş olduğu söylenebilir. Ancak, son filminde karakter derinliḡi ve olay örgüsünün belli oranda gerilim unsuru yaratmasıyla, her zaman koruduğu minimalist yapıya rağmen, filmografisindeki diğer filmlerden önemli ölçüde ayrıldığı göze çarpar. Aslında, bunun tam anlamıyla bir kopuş olduğunu söyleyemeyiz. Çünkü, Ceylan diğer filmlerinde var olan ağır ritmin getirdiği durağanlık ve karamsarlığı bu filminde de korurken, diḡer yandan 'nötr' diyebileceğimiz bir anlayışın yerine eleştirel okumayı bünyesinde barındıran ve hakiki anlamda 'karamizah' ölçütüne uyum sağlayan toplumsal ve felsefi duyuşu yeniden üreten bir derinliğe yönelmiştir.

Sinema aracılığıyla yeniden yaratılan bu felsefi bakış, incelikli görsel düzenlemeler nedeniyle metnin katmanlarının açılmasını sağlayan 'diyalojik' ve 'ideolojik' yapılanmayı olanaklı kılar. Ceylan, yaptığı filmlerde 'apolitik' bir duruş sergilediği yönünde eleştirilmiştir.' Sanatçının kendi yapıtına yaklaşımı ile filmin yorumcuya/seyirciye ulaşmasından sonraki aşama arasında bazı ayrımlara gidilebilir. Filmi analiz ederken bulgulanan semptomlar, imge ve görsel anlamların karşılıklarının okunmasını sağlar. Umberto Eco (1994:16) 'açılış' kavramıyla '...durağanın, belirlenmişin, tek-anlamlının yadsınması'nı işaret eder. Buna göre sanat yapıtı artık sağlam bir temele dayalı, güzelliği hayranlıkla seyredilen bir nesne deḡildir. Açımlanacak bir giz, yerine getirilecek bir ödev, imgelem için bir uyarıcıdır. Bir sanat yapıtı (bir film), yaratıcısının elinden çıktıktan sonra her ne kadar fenomenolojik bakımdan öznelliği barındıran yapıları hissettirse de, Terry Eagleton'ın, Raymond Williams'ın eleştirel kuramı doğrultusunda aktardığı 'alan' "toplumsal ilişkilerin, kültürel kurumların ve öznelliğin biçimlerinin etkileriyle kurulmuş bir uzamdır." (Eagleton, 1994:104'den). Bu yaklaşım, 'Bir Zamanlar Anadolu'da' için de geçerlilik taşır. Filmdeki 'alan', bu bağlamda, zaman-mekân algısının diyalojik ve ideolojik bir düzleme oturtulmasını taşra/kasaba kronotopu üzerinden derinleştirerek öngörür. Bu öngörü doğal olarak sinema dili, anlamlandırma ve görsel imge yaratımı ile katmanlaşarak söylemsel anlamda okunabilir hale gelir.

\section{Zaman-Mekân Algısı ve Nuri Bilge Ceylan Sineması'nda 'Kasaba' Atmosferi}

Nuri Bilge Ceylan Sineması'nda bugüne değin var olan 'zaman' algısı, durağanlık izlenimi veren derinlikli ve dikey bir süreç yaratma üzerineydi. 'Bir Zamanlar Anadolu'da' ile birlikte (bu sürecin bir bakıma Üç Maymun ile başladığını söyleyebiliriz), lineer yapı sık sık açılan kırıklar ve çukurlardan (bir anlamda mekânlardan), zihnin kendi zamanlarını ortaya çıkaran bir uzam-zaman'a ulaşır. Bu noktada hikâye yine bir araç gibi kalır.

'Zaman' konusuna farklı bir yaklaşım getiren Henri Bergson, Time and Free Will (1889) adlı yapıtında, özgür alanın 'zaman ve mekânın' dışında kaldığını söyleyen Immanuel Kant'a karşı çıkar. Bergson burada, Kant'ın öne sürmüş olduğu zaman ve mekânın birlikte yürüdüğü ve insan hareketinin doğal nedenlerden dolayı belirlendiğ inancına karşı bir görüş öne sürerek bu iddiayı iki katına çıkarır. Bunlardan ilki bilinçliliği (bilinci) ve bu nedenle özgür alanı tanımlamaktır. Çünkü, Bergson zaman ve mekânın ayrımını, yani 'to un-mix'i (yapının ayrışması anlamına gelen bir kavram) önerir. Diğer yandan, bu farklılık doğrultusunda daimi bilincin anlık bir veri olduğunu söyler. Bu da tıpkı süreklilik (duration-la dureé) gibidir. Süreklilikte olaylara ilişkin bir diziliş yoktur, bu nedenle mekânik bir nedensellikten de söz edilemez. Bergson'a göre sürekliliği niteliksel çeşitlilik (niceliksel çeşitliliḡin tezatı olsa bile) gibi algılamamak gerekir (1950: 76-77). Çünkü, Bergson ölçülebilir zamanın somut değil soyut olduğunu belirtir. Buna göre; "insan bilinci akış içindedir ve somut zaman fikri de bu bilinç akışının kendisidir." (Ünlü, 2009: 22). Bir Zamanlar Anadolu'da' da, yukarıda bahsedildiği üzere lineer gibi görünen, bir hikâyenin çatlaklarından içeriye sızan zihin dünyasını, hem epik bir anlayış hem de karakterler bazında giderek açılan ve 'diyalojikleşen' zaman-mekân algısını oluşturur. Jale Parla'nın (2007: 258) ifadesiyle; "geçmiş, 
'yaşanan an'ın parçaladığı ve yeniden anlamlandırdığı, bu yeniden anlamlandırmayla birlikte yaşanan an'ın bir kez daha parçalanmasına yol açan bir anımsayıştır".

Michael Bakhtin (2001: 315), "Edebiyatta sanatsal olarak ifade edilen zamansal ve uzamsal ilişkilerin içkin bağlantılılığına kronotop" adını verir. Zaman-uzam anlamına gelen kronotop için Bakhtin, bir edebi yapıtta karşılaşma, yol, şato, eşik ve taşra/kasaba tiplerini tanımlar. Einstein'in Görelilik Kuramı'nın bir parçası olarak geliştirilen bu kavram, uzam ve uzamın dördüncü boyutu olarak zamanın birbirinden ayrılmaz bir bütün olmasını ve bir edebi yapıtın fiili bir gerçeklikle ilişkili sanatsal bütünlüğunnün de ancak zaman-uzamıyla tanımlanması gerektiğini belirtir. Bakhtin (2001: 316) bu noktada; "Edebiyatta ve sanatta, zamansal ve uzamsal belirlenimlerin birbirinden ayrılamaz olduğundan ve daima duyguların ve değerlerin izini taşıdığından" bahseder.

Nuri Bilge Ceylan Sinemasi'nda 'Koza'dan bu yana kendisini ağırlıklı olarak hissettiren mekân (daha sonraki yapımlarında kentle ilişkilenen öyüler olsa bile) kasabadır. Kasaba, hem sınırlarıyla içine hapsettiği doğallıktan bunalıma kadar genişleyen sıkıntıyı, hem de sınırları dışında yaşanılan kopuş ile birlikte eski bağları yeniden hatırlatan bir aidiyeti zaman-uzam bağlamında kavramsallaştırır. Sıkıntının döngüselleşmesinin nedeni bir bakıma kaynag̃ııı 'kasaba' atmosferinin sürekliliğinden alır.

Bakhtin (2001: 322), kasabaların, döngüsel zamanın mahalleri olduğunu söyler. Burada hiçbir olaya rastlanmaz, yalnızca kendilerini sürekli yineleyen etkinlikler bulunur. Zaman, ilerlemekte olan hiçbir tarihsel devinim barındırmaz. Bunun yerine dar devirlerle ilerler; günün, haftanın, ayın, bir kişinin yaşamının devridir bu. Her gün durmadan, aynı etkinlikler döngüsü yinelenir: "Bu tip bir zamanda insanlar yer, içer, uyur... karıları, metresleri olur, küçük entrikalar çevirir, dükkanlarında oturur, dedikodu yaparlar. Sıradan, alalade, döngüsel bir zamandır bu” (Bakhtin, 2001: 322).

Nuri Bilge Ceylan'ın ilk üç filmi; 'Koza' (1995), 'Kasaba' (1997) ve 'Mayıs Sıkıntıı'nın (1999) ağırlıkı olarak Anton Çehov etkileri taşıdığı görülür. 'Kozáda, diyalog yoktur, ilişkiler tanımlı değildir. Bu üç filmde de denge doğaüstü gelişmelerle bozulmaz, hiç değişmeyecekmiş gibi duran koşullaryaşamınakışı içinde çokküçük değişikliklerlebozulur. Insanlar kasabanın ötesinden habersizdirler, birbirleriyle çelişirler, kendi küçük dünyaları içinde kaybolmuş gibidirler (Atam, 2011: 179-187). Ağır bir ritme sahip olan bu üç film, aksiyonu sürekli hatırlatmak yerine 'ölü zaman' diye tabir edilebilecek bir biçime sahiptir. İşte bu noktada 'ölü zaman' tercihi, karakterlerin yaşayan, düşünen, hisseden birer varlık haline gelmesi içindir. Böylece, durağanlık izlenimi üzerinden bir tezatlık yaratılarak daha derin bir iç dünya kazandırılmaya çalışıımıştır. Yönetmen burada insan-doğa bileşiminden bir atmosfer yaratıp ses ve müziğe gereksinim duymaz. Bu filmlerde yönetmenin öznel dünyası açısından düşünüldüğünde 'kasaba' aynı zamanda 'Baba/Yasa' ile bir çatışma alanı haline gelmektedir.

'Bir Zamanlar Anadolu'da' filmi de, bu açıdan, taşra/ kasaba kronotopundaki belirleyici noktaların karşılık bulduğu sıkıı bir döngüselliği işaret eder. Ceylan, oldukça rağbet ettiği Rus yazarların yapıtlarında yarattıkları atmosferi, yerel doku ve özelliklerden evrensel bir boyuta doğru genişletir. Özellikle Çehov'un oyunlarındaki üslup özellikleri, atmosfer yaratımı ve karakter derinlikleri Bir Zamanlar Anadolu'da ile benzerlikler taşır.

Tüten Özkaya (1977: 254), Çehov'un tiyatrosunun "Onun oyunlarında olay örgüsü bir tarafa itilmiş, bunun yerine birbiriyle bağlantısı olmayan ayrı ayrı olaylardan oluşan sahnelere ve günlük yaşamdan pek çok ayrıntıya yer verilmiştir. Özel ve önemli herhangi bir olayı değil, rastgele ele aldığı önemsiz sayılan bir zaman diliminde tüm yaşam, başı ve sonu olmayan bir süreç olarak" sergilediğini belirtir. Bu ifade, 'Bir Zamanlar Anadolu'da' filminde yaratılan karakterler, öyü, mekân ve zaman özellikleri ile bağdaştırılabilir. Bu bağlamda filmle bir karşılaştırma yapılacak olursa, oykünün ana eksenini oluşturan bir cinayet ve cesedin aranması her ne kadar başat dramatik olgu olarak görünse de, bu arayış esnasında sık sık kesintiye uğrayan ve izleyiciyi ana eksenden koparan diyalog ve monologlar yapıyı kırar. Yukarıda tariflenen gündelik hayatın küçük açmazları içine sıkışıp kalmış, boğulan ve 
bunalan karakterler bu kopuşlar ile birlikte mercek altına alınır. Beş erkek, cesedin aranması sırasında 'manda yoğurdu' üzerine konuşurlar. Konuşmanın başlangııında, gece yarısı, hiyerarşik düzende giden üç arabayı uzak çekimle görürüz. Konuşmalar görüntüye dış ses olarak düşer:

"Komiser Naci: Gecenin bir vakti olmuş, herkesin kafalar güzel Doktor..Dinliyor musun Doktor?

Doktor: Dinliyorum..

Komiser Naci: Yahu zurnayız hepimiz, bu mal müdürü kalktı gitti..ben dedim, şimdi bu gitti ya, yalaka ya, illa bir şey getirecek. O bir yüksek amir gördü mü çalışır..

Arap Ali: Nedim Bey o.

Komiser Naci: Kim?

Arap Ali: Nedim..o zamanki mal müdürü..

Komiser Naci: Nedim medim değil, o zamanki mal müdürü, Şinasi...Nedim eskisiydi, Şinasi..

Arap Ali: Amirim, böyle kafayı arkaya ata ata konuşurdu, şişman..kel olan..

Komiser Naci: Galip Bey'in tayini çıtıktan iki ay sonra falan tayini çıktı bunun...Yav bu arkadaş iki tane garsonla beraber, iki tane garson almış yanına..üç tane tepsiyle çıkıp geldiler, koydular masanın ortasına arkadaş. Tepsiyi görsen ne dersin?

Arap Ali: Kebap..

Komiser: Ne dersin? Ettir yani. Yok abicim...Bu adam yoğurt, yoğurt..Nasıl yoğurt? Hani bildiğin öyle sulu mulu yoğurt değil yani, taş gibi yoğurt..Bunu böyle bıçakla kesiyorsun o şekilde.."

Konuşmanın devamında sahne değişir ve arabanın içine geçilir. Ön tarafta komiser Naci ve şoförü Arap Ali, arka koltukta ise doktor, ortada zanlı ve onun yanında polis memuru İzzet oturmaktadır. Görüntü, sıkışık bir mekanda beş erkeğin yoğurt muhabbetine odaklanarak ana öyküden kopar. Burada yönetmen, anlamsızlığın eleştirisini özellikle hissettirecek ölçüde figürlerin gerek yüz ifadelerine, gerekse kendi aralarındaki hiyerarşik düzene vurgu yapar:
"Doktor: Peynir falan olmasın?

Komiser Naci: Peynir mi? ..Doktor biz sence peyniri görünce anlamaz mıyız ya? Yoğurt mudur, peynir midir? Ne yaptın sen, bitirdin bizi.."

Arap Ali: Doktor, o çok güzel olur, bilhassa baharda, kıvamlı.."

Komiser Naci: Yok ya, peynir değil yoğurt..Yalnız yanlış anlaşılmasın, koyun falan değil, manda yoğurdu."

Izzet: Efendim, bizim lojmanın altındaki mandırada bu yoğurdun aynısından...

Komiser Naci: Nerede? Nerede lojmanın..hangi lojmanın altında?

İzet: Efendim bizim oturdug̃umuz lojmanın altındaki mandıra efendim..

Komiser Naci: Yahu sen benden ayrı bir lojmanda mı kalıyorsun? Hangi mandıra?

İzet: Bizim lojmanın altındaki mandıra var ya efendim, orada..

Komiser Naci: Kıvırcığın orayı diyorsun, aman geç..

İzet: Evet efendim, o adam bazen yapıyor..

Komiser Naci: Oğlum, pastörize len onunki..

İzzet: Ben yedim ama, kokuyor gibi geldi bana..

Komiser Naci: Yahu orada köşedeki büfe olsa ben bilmem mi manda yoğurdunu, hastasıyım ya..

Izzet: Vallahi bilmiyorsunuz komiserim. Ben yedim ondan ama biraz kokuyor gibi geldi..

Arap Ali: Ya işte güzel olduğu için kokuyor..

Komiser Naci: Kokuyor mu? Bazı insanın hiç ağız tadı yok değil mi Arap ha? Ben manda yoğurdu diyorum adam kokuyor diyor, niye? Çünkü hakikisini bilmiyor..

İzzet: Ya komiserim ondan demedim, aslında benim annem de yapıyordu ama, onun gibi yapamıyor.

Komiser Naci: Şimdi bazen gerçekten kafam takılıyor ha, markette görüyorum, kaymaksız yoğurt, ya arkadaş insan yazmaya utanır, kaymaksız yoğurt ne demek?". 
Konuşma, hiyerarşik açıdan daha alt kademede olan Arap Ali ve polis memuru İzzet'in, amirleri durumundaki Naci'ye her koşulda hak vermeleri üzerine yapılanır. Mutlak itaat ve mutlak aidiyetin mikro bir örneğini sergiler. Konuşma sırasında arabanın içindeki zanlının yüzüne ağır ağır zoom yapılır. Böylece, ana öykünün çatlaklarından sızan yan konuşmalarla yabancılaşma, görsel dilin katmanlı yapısı ve eleştirel boyut daha da açığa çıkar.

Benzer bir şekilde, ilerleyen dilimde asker, savcı, komiser ve doktor arasında geçen ve sık sık tekrarlanan 'mücavir alan' konusu; yine Doktor, Arap Ali, komiser Naci arasında geçen 'prostat' mevzusu eksen öyküyü kırar. Bu kırıklardan hem kasaba insanının gündelik hayatına dair kurulan boş ve anlamsız diyalogun kısırdöngüsel alanı hem de karakterlerin içinden çıkamadıkları boşluk, çoraklık ve döngüsel çıkmazın fiziki olduğu kadar psikolojik ve zihinsel anlamda da bir yokluğu ve çıkmazı işaret ettiği vurgulanır. Cesedin aranmasına devam edilmektedir. Komiser Naci karısıyla bir telefon görüşmesi yapar. Kadın durmadan söylenir ve Naci içinde bulunduğu konum itibarıyla karısı karşısında suçlu, ezik ve bir bakıma iktidarsız kalır. Diğerleri durumun farkındadır. Bu sahnenin ardından iktidar konusunu pekiştirecek ve durumu diyalojikleştirecek olan "prostat" konusu gelir. Böylece, Naci'nin az önceki "iktidarı kaybetme" endişesi, hem bürokratik hem fiziki bir boyutla düzlem deḡiştirir. Sahne hiyerarşik düzene göre ön sırada olan savcının arabasının farklı bir düzene geçmesi ile devam eder. Ön sıradaki savcının arabası durur:

"Komiser Naci: Ne oldu şimdi? Niye durdu ki bu? (Savcının arabasına doğru seslenir.)

Komiser Naci: Noldu?

Savcının şoförü: Ben bu yolu hep karıştırıyorum, siz öne geçin komiserim.

Komiser Naci: Peki

Arap Ali: Yol bilmezsin, iz bilmezsin ama adliyeye şoför olmayı bilirsin.

(Arap Ali aynadan geride kalan savcının arabasını kontrol eder.)
Komiser Naci: Niye gelmiyorlar ki bunlar?

(Savcı arabadan çıkar ve hacetini görmek için yer arar.) Komiser Naci: Bu kaçıncı oldu yahu? Üç mü, dört mü? İzzet: Efendim ben saydım, bununla beraber beş oldu. Komiser Naci: Doktor, prostat değil mi bu? Doktor: Belli olmaz, olabilir de, olmayabilir de.. Komiser Naci: Beş kerede de mi belli olmaz? Doktor: Vallahi muayene etmeden anlayamayız. Komiser Naci: Ben gece bir defa kalkarım, bir de çok su içtiysem ikinciye işte..(doktora döner) Normal değil mi?

Doktor: Gece bir kereden bir şey olmaz canım, gayet normal. Ama belli bir yaştan sonra kontrol ettirmekte fayda var. İsterseniz sabah geleceksiniz ya, o zaman muayene yapabiliriz..

Komiser Naci: Yok yok, Allah göstermesin.

Doktor: Neden?

Komiser Naci: Ben o işin nasıl yapıldığını biliyorum. Bizde bir şey yok, ama sen savcıyı bir kontrol et. (Arap Ali ve İzzet kendini tutamayarak gülerler)

Arap Ali: Geliyor..."

Konuşma bittiğinde arama mahalli olan üçüncü çeşmenin bulunduğu yere geldikleri zaman, savcının arabası hızlı bir manevra yaparak sıranın başına geçip park eder.

Böylece gerilim, mücadele, suçluluk ya da suçsuzluk konumu; batılı anlamda varoluş̧̧u, doğulu anlamda tasavvufi yaklaşımın 'yokluk/hiçlik' ve 'varlık' duyguları üzerine yükselen tezatlığı içinde kaybolup gider. ${ }^{2}$ Özkaya, filmle benzerlikler taşıyan Çehov'un oyunlarındaki durumu, mücadele olmamasının sebebinin suçlu olarak adlandırılabilecek kimsenin bulunmamasına bağlar:

Hiçbir kahraman bilinçli olarak diğerlerinin mutluluğunu engellemez, kahramanların birbirini sevmesinde ya da sevmemesinde yine kimse suçlu değildir. Oyun kahramanları güçsüzdür. Yaşamın önemsiz ayrıntıları içinde şaşırıp kalırlar, debelenip dururlar ve bunlardan 
bir kaçış, çıkış yolu bulamazlar. Yaşam boş yere gelip geçer. (Özkaya, 1977: 257-258)

Böylece filmde kurulan diyaloglar veya monologlar tıpkı içinde dönüp durdukları zaman gibi bir yere ulaşmaz. Bu 'varamama' duygusunun diyalojik bağlamda es geçiliyormuş yanılsaması, aslında diyalojikleşerek hiçliğin, boşluğun ve dolayısıyla Anadolu insanına özgü derinliḡin/derinliksizliğin anlamını kültürel ve zihinsel düzlemde yaratır.

\section{Hiyerarşi, Bürokrasi, Düzen ve Aidiyetlik Üzerinden Bir Değerlendirme}

Gabriel Garcia Marquez' in 'Kırmızı Pazartesi' adlı yapıtının temellendiği ana düşünce; 'herkes her şeyi biliyor ama kimse bir şey söylemiyor' cümlesiyle özetlenebilir. 'Bir Zamanlar Anadolu'da', gündeme geldiği tarihten bu yana gerek isim benzerliği, gerekse karakterler arası iletişimiyle (Ceylan da bu etkileşimi yadsımaz) özellikle Sergio Leone'nin 'Bir Zamanlar Batı'da' (1968) filmiyle benzerlikler taşıdığı yönünde dile getirilmiştir. ${ }^{4}$ Bir cesedin aranılmasına odaklanan 'Bir Zamanlar Anadolu'da'nın, birbirlerine hiyerarşik ve bürokratik ilişkiler ve dolayısıyla aidiyet üzerinden bağlı olan bir topluluğa ait figürlerin içerik çözümlemesi bakımından fikren 'Kırmızı Pazartesi' ile daha yakın bir şekilde ilişkilendirilebileceği sonucuna varılabilir. Bu nedenle filmin okunması, zihniyet, bürokrasi ve hiyerarşi ilişkilerini de çözümlemekten geçmektedir. Sıradan bir kasaba ortamında (özellikle orta Anadolu düşünüldüğünde) en fazla dikkati çeken durumlar, bağlılıklar/bağımlılıklar, ast-üst zinciri, kişilerin gündelik çıkarları nedeniyle birbirlerinin açıklarını görmezden gelmeleri, ortak ve topluca davranma eğilimi vb. davranışlar olarak sıralanabilir. Sıkıcılık ve kısırdöngüsel durum ise daha çok yarıbilinçlenmiş ya da 'aydınlanmış!' denilebilecek bireyin bu bağlıık, bağımlılık ve aidiyet nedeniyle bulunduğu sınırların içinden çıkamamasıyla baş gösterir. Filmde konuyla ilgili uyum sağlayan en önemli karakterlerden birisi komiser Naci'nin şoförü Arap Ali'dir. Arap Ali'nin karakter özelliḡi 1980 sonrasında devlet dairesi çalışanlarına özgü yapılanan 'işini bilen' küçük devlet memurunun 'günü kurtarma çabası' biçiminde yorumlansa da bu davranış biçimi ile ilgili oluşumlar daha eskilere dayanmaktadır. Filmde, bu derinlikli ve kendi içinde sürekli çatışan karakter özelliğinden dolayı Arap Ali, diğerlerine göre daha fazla ön plana çıkar. Daha üst düzeydeki çatışmalar ise komiser $\mathrm{Naci}$ ve savcı, doktor ve savcı, savcı ve jandarma çavuşu arasında gözlemlenir.

Filmin geneline bakıldığında en fazla, düzenin korunması, hiyerarşi ve bağlıık/bağımlılık ilişkilerine vurgu yapıldığı görülür. Hiyerarşi ve düzen bir bozkırda, bozkırın kıvrımlı yollarında, devletin resmi organlarını temsil eden üç aracın hiyerarşik bir düzen içinde ilerlemesi olarak resmedilir. Genel çekimle gösterilen bu düzen vurgusu, daha yakın planlarda bu zinciri oluşturan aktörlerin karşılıklı diyaloglarında (ya da üste riayet eden ve bazen neredeyse hiçbir 'diyalekt'e izin vermeyen diyalogsuzluk eleştirisinde) ve karakterlerin ince çarpışmalarında belirginleşir. Araçların dizilişi, başta hükümeti temsil eden savcının, arkasında emniyeti temsil eden komiserin, en sonda da orduyu temsil eden jandarmanın aracı biçimindedir. Aslında bu görüntü bile politik bir eleştiriyi karamizah duygusuyla harmanlayarak günümüz Türkiye'sine ait bir takım değerlendirmeler ve anlam oluşturan yorumlar biçiminde analiz edilebilir.

Nuri Bilgin, 'Komünotenin Varoluşsal Matrisi Olarak Mekân' başlığında, mekânın sosyal varoluşun matrisi olarak insanlar arası ve çevre arası iletişimleri şekillendirdiğini belirtir. Mekân içinde gerçekleşen, mekânı belirleyen ve ona bir anlam kazandıran da ilişkilerdir. Nuri Bilgin'in 'Yakın Düzenler' olarak adlandırdığı bağlam duygusal ilişkiler üzerine şekillenmiş, irrasyonel iletişim biçimleridir:

Duygusal ilişkiler, bireyin dig̈erleriyle, fonksiyonel ilişkiler kurmak istediği (veya istemediği) ilişkilerdir. Burada herhangi bir fonksiyonel neden olmaksızın, isteğe bağlı karizmatik bir iletişim söz konusudur. iliş̧kide olmak, iletişimin içeriğinden daha önemlidir. Hiyerarşik ilişkiler, şu veya bu nitelikte bir otorite yoluyla karar alma, emir verme ilişkilerini kapsar; kimin kime emir vereceğini, kimin kime karşı sorumlu olacağını belirtirler. (Bilgin, 2005: 162)

Ancak, filmde özellikle dikkat çeken ve Anadolu insanının temel davranış biçimi olarak şekillenen durum, kişilerin özellikle 'fonksiyonel' ilişkiler kurmalarıdır. 
Gündelik hayatı oluşturan durum, Nuri Bilgin'in yukarıda belirttiği gibi 'karizmatik ilişkiler' de dahil olmak üzere, ağırlıklı olarak fonksiyonel ilişkiler üzerine temellenmiş görünmektedir. Şerif Mardin (2002: 14), ideoloji konusunu tartışırken, 'vaziyet alış'tan söz eder: "Vaziyet alış (attitude), bir insanın - dünyanın diğer görünüşlerinden ayırt ettiği bir dünya görüşü karşııında - davranışlarından çıkarılmış psikolojik süreç örgütlenmesidir". Dolayısıyla bu vaziyet alış, filmdeki memur (ast-üst derecelendirmesi dahilinde) profili açısından, bir bakıma geleneksel, kültürel, zihinsel ve tarihsel süreçlerin günümüz Türkiye'sindeki son yüzeyini figürler nezdinde temsil eder niteliktedir. Şerif Mardin, 'memur'a ilişkin bu geleneksel-aktarımsal yapıyı, Türk iktisadi yapısının belirlenmesinde 'arpalık' mükâfatlarının önemli ve gizli bir değişken olduğu yönünde açıklar:

Türkiye'de devlet, yüksek memurlarına her zaman iktisadi fırsatlar sağlamıştır; akıllıca kullanılırsa, bunlar, özel teşebbüsçülük için doğrudan doğruya işe atılmaktan daha iyi bir atlama taşı olmaktadır. Bu, maaşların yüksek oluşundan değildir. Gerçekte devlet hizmeti yapanlara verilen maaş yetersizdir. Fakat bürokrasi ile ilişkiler, iş hayatında şart olan kapıları açmaktadır. Türkiye'de özel sektörde başarı göstermenin en iyi yolu devlet memuru olarak başlamaktır. (Mardin, 2002:141)

Film, bu ifadeye göre düşünüldüğünde, hem günü değerlendiren hem de yaşadığı her günden ve her olaydan kendisine bir kazanç sağlamaya çalışan 'memur' tiplemesinde başat hale gelir. Yukarıda sözü edilen 'yoğurt' muhabbeti de hiyerarşik düzenin zihniyetle bağlantılı bir şekilde sürdürüldüğünü imleyen başlıca durumlar ve sahneler arasında en önemlilerinden birisidir. Bu sahnede kamera, zanlının yorgun ve öfkeli yüzüne ağır ağır yaklaşır. Dolayısıyla Bergson'un “durağanlık üzerinden imge yaratılması” (Totarro, 1999) ile Bakhtin'in 'diyalojik' kavramını açımlayan bir anlam yaratma süreci başlar. Bakhtin'e (2001: 353) göre, esas olarak çoğul konuşan özneler arasındaki anlam ilişkisini tanımlayan 'diyaloji' "ne tümüyle mantıksal (diyalektik olsa bile) ne de tümüyle dilsel olana (komposizyonel-sözdizimsel anlamda) indirgenebilir". Bir bakıma 'çokseslilik' anlamına gelen diyalojik ilişki; "söylem iletişiminde her tür sözce arasındaki (anlamsal) ilişkilerdir. Herhangi iki sözce, anlamsal bir düzlemde bir arada, yan yana bulunuyorlarsa (şeyler ve dilsel örnekler olarak değil) diyalojik bir ilişki kurarlar". Bu noktada 'anlamın cisimleşmesi' olarak da tanımlanabilen diyalojik ilişki "anlamın anlam üzerinde, sesin ses üzerinde katmanlaşması, kaynaşarak güçlenmesi (özdeşleşme anlamında değil) birçok sesin (bir sesler dehlizinin) anlamayı arttıran bileşimi, anlaşılmış olanın sınırları ötesine geçiştir" (Bakhtin, 2001:353). Bu nedenle, komiser üzerinden gelişen 'yoğurt' konusu, savcı üzerinden gelişen 'prostat' konusu diyalojikleşme bağlamında önem taşır. Komiser ve savcı arasındaki çatışma ('biz çalışalım halayı sen çek'çıkışı), muhtarın evindeki yemek sahnesinin neredeyse tamamı hem diyalojik ilişki yaratımı hem de durağanlık üzerinden imge yaratımı konusunda Bakhtin'ci ve Bergson'cu tavırla örtüşür.

Hiyerarşik düzende ast-üst ilişkilerinin çok daha net biçimde vurgulandığı önemli sekanslardan biri de, cesedi arayan ekibin bir mola için Muhtar'ın (Ercan Kesal) evine konuk oldukları bölümdür. ìktidar zincirine sonradan eklemlenmiş gibi duran, kendi sınırları içinde iktidarla ilişkiye geçebilen tek kişi olarak 'muhtar' ve diğer erk sahipleri arasındaki iletişim biçimi bu kez daha farklı bir zihniyet ve aidiyet alanını ortaya çıkarır.

Muhtar, büyük adamları evinde ağırlamaktan, onlara ziyafet vermekten son derece hoşnut görünmektedir. Muhtarın büyük adamları doyurması, bir bakıma onlara hediye vermesi, Marcel Mauss'un (2005: 203-236) 'potlaç' tanımına uyum sağlayan, iktidarın el değiştirmesi ve karşılıklı alışverişe dair bir zihniyet ve davranış modelinin Türkiye'deki kalıpsal/aktarımsal dışavurumunu ortaya çıkarır.

Muhtarın köye bir morg ve gasilhane yaptırmak istemesi, bu ödeneğin devlet tarafından çıkartılması talebi, bu sekansta yer alan savcı, muhtar, komiser arasında geçen konuşma örgüsü, diğer sekanslarda olduğu gibi farklı olay, durum ve duygu katmanlarının birleşerek anlam yaratılmasına olanak tanır. Bu noktada, 'ikram' meselesi iki ayrı durum üzerinden, iki ayrı çözümleme imkânı tanıyan günümüz Türkiye’sine ilişkin bir takım politik çıkarsamaları da yorumlamayı gerekli kılar. Bunlar, muhtarın geniş ziyafeti 
ile (farklı bir sekansta) jandarma komutanının savcıya yaklaşabilmek ve iletişim kurmak amaçlı 'bisküvi' ikramıdır. İki ikram biçimi karşılaştırıldığında, jandarma komutanının çabası çok cılız kalır. İşgüzarlık (ya da farklı bir perspektifle bürokrasi) konusunda, sonu hiçbir yere varmayan ve bir cesedin aranması işleminde yararsız bir bilgi olarak boşlukta kalan 'mücavir alan' takıntısı, tıpkı bürokrasiyi gerektiren diḡer mevzularda olduğu gibi (ceset torbası, cinayet tutanağı, otopsi sırasında memurun malzeme yetersizliğine dair yakınmalarına ilişkin konuşma örgüsü) asıl konuya hizmet etmeyen, işlevsiz ve gereksiz bürokrasi yığını olarak eleştirel bir alt okumayı yaratır.

Tüm bu anlamsızlıklar yığını, tek tek karakterlerin içinden çıkamadıkları bir döngünün sıkıntısı ve bunalımı olarak (karamizahi ve absürt durumların da yaratılması suretiyle) resmedilir.

Elias Canetti (1998: 94), ‘sürü' türlerinden söz ederken "sürüde görece az insan bulunur ve bu insanlar birbirini iyi tanır... her zaman birlikte yaşamışlardır, her gün görüşmüşlerdir ve pek çok ortak girişimde birbirlerini değerlendirmeyi öğrenmişlerdir" der. Canetti'nin sürüye ilişkin bu tanımı, aslında daha genişlemiş haliyle kitleyi oluşturur ve bu tanım bir cesedin peşinde küçük dünyalarının anlık coşkusunu ve çıkarlarını yaşayan filmdeki küçük topluluk için de geçerlidir. İktidar ve itaat zinciri düzenin (ya da oyunun) bozulmaması adına, küçük öfke patlamaları, geleceksizlik duygusu, suç ortaklığının zaman zaman verdiği vicdani ağırlıklar bazında yaşansa da sürmeli, sürdürülmelidir.

\section{Bir Erk(ek) Analizi ya da Otopsisi}

'Bir Zamanlar Anadolu'da'nın ve genel olarak Nuri Bilge Ceylan'ın son dört filmi 'kadının ikinci plana itildiḡi' yönünde okunmuş ve 'erkek' filmleri olarak değerlendirilmiştir.

Ceylan, 'Anadolu sorunu, kadın sorunu mudur?' sorusuna cevap olarak, filmlerini kadın ya da erkek sorununu ön plana almak için yapmadığını, daha çok insanlık sorunu diye adlandırabileceğini belirtir. Temel motivasyonlarda kadın ve erkeğin arasında çok fark olmadığını ifade ederek örneğin; köyde (muhtarın evinde) erkeklerin karşısına çıkan melek yüzlü kızın (Cemile'nin) erkeklerde o an için bıraktığı etkinin yansımasından söz eder. Kadınlar bazen (özellikle dar zamanlarda) erkeklere mucize gibi görünebilir, zanlının itiraf etmeye karar vermesi gibi. Filmde bu 'güzellik' imgesinin herkesi kendi içinde farklı hesaplaşmalara götürebileceğini söyler. 5

Yönetmen her ne kadar bu tür bir niyetle filme başlamadığını belirtmiş olsa da, ağırlıklı olarak 'erkek'lerin ön planda olduğu ve kadının gerek bir 'güzellik' kavramı, gerekse bir 'suç unsuru' olarak çok kısa dilimlerde ortaya çıkması, filmin yine de kadın ve erkek profilleri açısından okunmasını gerekli kılar.

Filmde, anlık öfkeler, patlamalar, örtük çatışmalar, hınç ve benzeri duygulanımlar erkekler arasında, erkeklerin dünyasında ve erk(ek)'e özgü bir şekilde yapılanır. Bu noktada 'erk'e ilişkin olan tüm ilişki ve iletişim biçimleri doğal olarak 'erkek' kaynaklı bir görünüm kazanır (ya da bunun tam tersini de söylemek de mümkündür). Ancak, baskın olarak hissedilen bu erk'in arka planında 'kadın' vardır. Kadın genelde (komiserin söylemiyle işleri karıştıran) kafa karıştırıcı, etkileyici, varlığı ortadan kalkmış olsa bile (savcının ölen karısı) gücünü hala sürdüren ve dikte edici bir tonda filmin dokusuna işler. Psikanalitik açıdan düşünülürse, filmde kadın imgesi, erkek nevrozunun Ödipal kırılmasına bağlı bir şekilde her erkek karakterde ayrı ayrı tezahür eder.

Freudien anlamda nevrotik ya da irrasyonel dışavurumlar, bastırılanın yerine geçer. Kısacası filmde 'kadın' erkeğin nevrozu olarak vardır. Ancak, bu nevroz çeşitli kastrasyon aşamalarından geçerek temeli ‘anne'ye dayalı olan bir kadınlık imgesi olarak belirir. Freud (1989: 136), en başından itibaren, anne ile çocuk arasındaki evreyi, "kadının edilgen duruma geçmek için etken olması gerektiği” biçiminde tarifler. Bu dolaylı etkenlik (ya da bir bakıma görünmez iktidar), anne ve erkek çocuk arasında fort-da ${ }^{6}$ oyununun da içinde olduğu çeşitli aşamalardan geçerek, erkek çocuḡun hayatı boyunca 'anne'ye ilişkin eksiği kapatma, süblime etme ya da bastırma biçiminde sürer gider. Gledhill'e (1987: 12) göre Freud, bu anlamda, "biri iyi, diğeri kötü olan iki sembolik anne yapılandırır, bakıcı/koruyucu ve cezalandırıcı anne olarak.." 
Filmde, tam da bu anlamda iki ayrı kadın, Cemile ve Gülnaz, iki ayrı kavramı temsil eder niteliktedir. Biri suçu, vicdanı, ölümü temsil eden 'Gülnaz', bir bakıma 'şeytan kadın' imgesini üstlenirken; diḡeri 'koruyucu, bakıcı, fantazmı güçlendirici, duygu yapıcı/duygusallaştırıcı' olarak 'Cemile', 'melek kadın' imgesinin erkek zihnindeki tezahürleri olarak ortaya çıkar. Bu iki kadına ilk etapta her ne kadar birer kavram ya da imge olarak yaklaşılsa da, erkek karakterlerdeki gerçekliğin bir yansıması biçiminde, yani erkeklerin kadınlara ilişkin deneyimleriyle ilgili bilinçaltı görüngülerini yüzeye çıkartmak için var oldukları anlaşılır. Bu deneyim ve görüngülerden ilki savcı ve sır perdesi olarak kalmış olan karısının ölümüdür. Gerek Freud gerekse Lacan'ın 'şey' ya da 'muamma' olarak belirttikleri kadın tanımı, artık ortada olmayan, aldatılmaya rıza göstermeyip kendisini yavaş yavaş ölüme sürükleyerek geride kalan kocasına ağır bir vicdan yükü bırakmış olan, bir nevi onu cezalandıran kadın imgesidir. Film boyunca, kadının varlığını hissettiren ilk efekt, komiser Naci'nin karısıyla yaptığı telefon konuşmasında belirir. Bu kadın sesi, o an’a kadar iktidar, irade, sorumluluk ve erk'in verdiği üstünlük duygusuyla komiser Naci'yi farklı bir hiyerarşik pozisyonda tutan durumun tersine çevrilmesiyle karamizahi, nevrotik ve diyalojik bir alan yaratır. Telefondaki kadın sesi dikte edici ve buyurucudur. Doktor'un hikayesine gelince, Doktor mutsuz bir evliliği geride bırakıp taşraya alışmaya çalışan, mesafeli, çocukluğundaki gibi yalnız ve kırılgandır. Bu aşamada yine 'anne' temelli bir kırılma, çocukluğuna ait bir fotoğraf aracılığıyla ve Gülnaz’ın oğlunu uzaktan izlemesiyle ima edilir. Filmdeki en derinlikli karakterlerden biri olan Arap Ali, trajik boyuttan varoluşsallığa, itaatkar bir 'kul' görünümünden Çehov kahramanlarının $\mathrm{acl}$ acı gülümseten karamizahi karakterlerine uzanan katmanlı bir yapı sergiler. Arap Ali'nin 'kadınla imtihanı' ise, muhtarın köyünden evlendiği kadındır. Ali'nin ihtilaflı olduğu köy muhtarı ile arasındaki soğuk savaş evlendiği kadın aracılığıyla, organik bir bağ haline gelen bir evlilik nedeniyle ne tam anlamıyla sonlanan ne de sıcak bir şekilde devam eden bir iletişim halidir. Bu aşamada en gerçek ilişki, Gülnaz ve zanlının ilişkisidir. O da yasak bir ilişkidir ve bir kişinin ölmesine neden olmuştur.

Tüm bu erkek karakterler içinde, psikanalitik anlamda kadınla en direkt ilişkiyi kuran kişi 'zanlıdır. Freud, "tatmin edilmeleri kolaylaştığı anda erotik ihtiyaçların psişik değeri azalır" der: "Libidoyu yükseltmek için bir engel gerekir, tatminin önündeki doğal dirençlerin yeterli olmadığı yerde de insanlar her zaman aşkın keyfini çıkarabilmek için kendi önlerine geleneksel engelleri çıkartmışlardır” (Sizek, 2002:123'den). Bu durumda, zanlının 'arzusu' ya da arzu nesnesi olan kadını kaybetmeye odaklı her girişiminde hazzı arttıran bir 'cinayet' ile fantezi boyutunu kaybetmeden devam eder. Sizek'in (2002: 123), Lacan'dan aktardığı müstehzi ifade; "Cinsel ilişki yokluğunu ikame etmenin çok incelikli bir yolu, onun önündeki engeli koyan bizmişiz gibi yapmaktır" biçimindedir.

Konu, erkek dünyasındaki 'anne' temelli 'kadın' olunca, yine dolaylı olarak anneyi ilgilendiren Ödip ve fallus etkinliğinden söz etmek gerekir. Çünkü, filmde özellikle 'erkeklik ve erkekliğin yitimi' doğrudan 'fallus'la ilişkilendirilebilen göndermeler taşır. Lacancı anlamda Ödip, önce anne ve çocuğun ortakyaşarlığıyla başlayan, babanın daha sonradan bu yapıya katıldığı bir süreçtir. Baba bu noktada 'Yasa'yı yani her şeyden önce aile içi cinsel ilişkiyi yasaklayan tabuyu temsil eder. Çocuk böylece baba figüründe kendisinin parçası olduğu daha geniş ailevi ve toplumsal bir düzen olduğunu anlamaya başlar. Fallus, Lacan'ın kilit terimidir ve cinsel farklılığı belirtir. Freud’a göre ise, erkek çocuğu annesine yasak aşk beslemekten vazgeçiren şey iğdiş edilme korkusudur. Bu aşamada babaya boyun eğme ve anneden uzaklaşma onu simgesel olarak erkek rolüyle tanıştırsa da, anneye ilişkin yasak arzunun ilk kez bilinçaltına gönderilmesi ile ilk içe bastırma başlar (Eagleton, 1990:173-193'den). Fakat fallus anne dolayımıyla hala bir tehdit oluşturmaktadır.

Filmde 'prostat' konusu doğal olarak daha geleneksel, hiyerarşik ve erkeksel/iktidara yönelik düzlemde gelişme gösterse de, alt metninde bir fallus tehdidi sezilmektedir. Filmde, hiyerarşik tablonun tepesindeki kişi olan savcının 'sıklıkla idrara gitmesi' üzerine diğer arabada bulunan komiser Naci, Doktor, Arap Ali ve polis memuru İzzet arasında geçen konuşmalar, Doktor'un açıklayıcı bilgilerine rağmen bir erkeklik yitimi önyargısıyla karşılık bulur. Bu makelenin 'Hiyerarşi, Bürokrasi, Düzen ve Aidiyetlik Üzerinden Bir 
Değerlendirme' başlığı altında sözü edilen hiyerarşik düzen ise (araçların dizilişinin sırasının değişmesi) tam da bu aşamada bozulur. Komiser ile savcı arasında daha sonradan ortaya çıkacak olan hiyerarşi temelli çatışmanın ilk belirtileri bu aşamada kendisini hissettirmeye başlar.

Sonuçta, bir 'erkek filmi' yolundaki düşünce ya da ön yargılar, erkekliğin yitimiyle ilgili korkuyu, fallik endişeyi, düzenin bozulması ya da bozulmasına ilişkin tehdidi ve erkeḡe yüklenen geleneksel baskının kristalize olmasını ifade eder. Bu çözülme ve deformasyonun filmdeki tek geçerli nedeni, anne temelli kadın olarak gösterilebilir. Yine Freudien anlamda, erkek çocuğun yoğun biçimde saldırganlaştığı evre, 'annenin aşkını yitirme' duygusunu yaşadığı (ya da bu duygunun ikamesini oluşturmaya başladığı) evredir. Film bu anlamda, erkek figürlerin hacimsel olarak yer aldığı bir mecrayı işaret ederken, imge olarak kadını ön plana çıkarır.

\section{Sonuca Doğru}

Nuri Bilge Ceylan'in son filmi 'Bir Zamanlar Anadolu'da' tartışılabilir düzeyde postmodern veya sanat sineması tanımlı bir film olarak ifadelendirilebilen, çizgisel ve basit bir öyküye sahip olmakla birlikte 'açılış'a elverişli, okunabilir bir yapım, hatta bir başyapıttır. Fakat, daha da önemlisi film, herhangi bir duyuşa ve kategoriye girmemesi bakımından tanımı hak eder ölçüde 'yeni' bir filmsel duyarlılığın (Türkiye sineması ve yönetmenin kendi filmografisi bağlamında) kapısını aralar.

Sinemada 'kalıcı olan'ın tanımı için, endüstriyel anlamda geniş seyirci kitlelerine ulaşması, ticari başarı elde etmesi ve teknik düzeyde son derece pahalı ya da çarpıcı unsurlar taşıması gibi özellikler akla gelirken; sanatsal düzeyde ise, anlam oluşturabilen, görsellik aracılığıyla katmanlaşarak okunabilir hale gelen, yarattığı metaforlarla düşünsel boyutu derinleştirebilen ve biçimsel estetiğinin kusursuzluğunu öyküyle örtüştürebilen yapımlar akla gelir. Jean Mitry (ikircikli olmakla birlikte), sonunda sinemanın bir dilyetisi olduğu sonucuna varmıştır:

Diğer tüm sanat biçimlerinde varolan eksilti (ellypse), anlama (syllepse), yineleme ve karşıtlıklar, karşı-tez, dolaylama, abartma, sıralama, derecelendirme, askıya alma, metafor ve kapsamlama sinemada da varlık bulmaktadır. Bu nedenle düşünceye bir kalıp veren dilyetisi, yapıları aracılığıyla kısmi düşünce biçimlerini ortaya çıkartmış, daha doğrusu düşüncenin sunduğu biçimler aracılığıyla üretilmesini sağlamıştır. (Mitry, 1989: 30-31)

Peki, sinemada sanat haline gelen veya onun dar anlamda 'sanat sineması' olarak tanımlandığı koşullar nasıl ortaya çıkar? Ya da soru, biraz daha Türkiye Sineması bağlamında düşünülürse, özellikle $2000^{\prime} l i$ yılların yapımları bu tanımlamayla örtüşür mü? David Bordwell, sanat sinemasını tanımlarken bilindik tarzdaki klasik anlatı sinemasının tezadında yer alan özelliklerden bahseder: Neden-sonuç ilişkisindeki kopukluklar, olay örgüsünde epizodik yapılanma, psikolojik gel-git'lere yapılan vurgu gibi (Bordwell, 2010: 126). Bu nedenle, bu tarz sinemanın gerçekliğinin çok yönlü olması, önceden hesaplanmış boşluklar (bir tür semptomatik okuma ile açıklayabileceğimiz tarzda) barındırması, nedenselliğe daha açı uçlu yaklaşımlar getirmesidir. 'Sanat Sineması Üzerine-Tartışmalar ve Yaklaşımlar'a önsöz niteliğindeki Ali Karadoğan'ın metni, Türkiye'de hala 'sanat sineması' kriterlerinin ya da bu sinemayı değerlendirme koşullarının netlik kazanmadığı yolundadır: Karadoğan (2010: 16), 2000’li yıllarda yapıtlarını sanat sinemasının anlatım özelliklerini kullanarak sürdüren ve taviz vermeyen yönetmenler arasında Nuri Bilge Ceylan, Zeki Demirkubuz, Semih Kaplanoğlu gibi isimleri sıralar, ancak bu yönetmenlerin sinemasında 'sanat' tanımı konusunda hala belirsizlikler olduğunu da belirtir. $\mathrm{Bu}$, ister sanat sineması ister daha sınırlanmamış haliyle 'yeni oluşumlara açık' bir sinema biçimi olarak düşünülsün, Bergson'cu anlamda 'psikolojik zaman', Bakhtin'ci anlamda 'kronotop ya da diyaloji', Eco'cu anlamda 'açık yapıt' ya da Barthes'cı anlamda 'boş sayfa' olarak değerlendirilebilecek bir yapıtla karşı karşıya olduğumuz söylenebilir.

Edgar Morin (2005: 61), bu psikolojik zamanın (equivocal time-çiftanlamlı zaman) duygusal ve öznel zaman olduğunu söyler: Geçmiş, şimdi ve gelecek örüntüsünü içinde barındıran bu zaman, tıpkı insan zihnindeki gibi ayırt 
edilmemiş (undiffentiated), geçişsiz (insanın geçmişe ait belleğinde geleceğe ilişkin imgeleminde ve yaşadığı an'a dair eşzamanlı ve birleşik) olarak sunulandır. Filmsel imge ve anlam yaratımı bu zemin üzerinden hareketle sadece yapısal düzeyde değil, gösterilenin yan anlamının kültürel, ideolojik ve psikolojik okumalarını da geçerli kılar.

'Bir Zamanlar Anadolu'da' hem açık uçlu denilebilecek hem de düşünsel düzeyde filmin bütününe yeniden göz atmamızı sağlayan ve ağırlıklı olarak dış sesle, efektlerle desteklenen ve yaklaşık yirmi dakika süren 'otopsi' sekansıyla hatırlanacaktır. Bu sekans yapısalcı ya da postmodernist anlamda post-politik bir görünümün yorumunu yapar gibidir. Cinayet çözümlenmiş, ceset bulunmuş, organların teşhisi yabancılaştııııı insan sesi ve organ sesi eşliğinde gerçekleştirilmeye başlanmış, cesedin canlı canlı gömüldüğüne dair bir kanıta rastlanmış ve derhal üstü örtülmüştür. Bu aşamada otopsi memurunun Doktor’a yönelik olarak sarf ettiği 'Hocam siz geri çıkın, size de kan bulaşmasın' cümlesi, o ana kadar katlanarak gelen cinayet, ceset, Komiser-Doktor çatışması ve malzeme yetersizliği üzerinden ve ceset üzerinde bulgulanan kanıın deşifre edilmemesi üzerine gelişen Doktor-Otopsi memuru çatışmasına etkileyici bir vurgu yapar. Çünkü, bu taşra kasabasına yeni katılmış olan Doktor'un da (yine açık uçlu bir okumayla) düzene dahil olmaya başlaması ve gerçeği beyan etmek yerine (gerek bürokratik nedenlerden gerekse duygusal/psikolojik nedenlerden dolayı) üstünü örtmeyi tercih etmesi, bireysel alandan toplumsal ve kültürel alana doğru açılan bir katmanlıık ve derinlik içerir.

Filmde Bergson'cu anlamda 'durağanlık izlenimi üzerinden imge yaratılması' konusuna uyum sağlayan ve nesneler üzerinden ilerleyen iki ayrı sekans anlam yapıcıdır. Bergson'un 'imge-hareket' (duration-images) ya da 'dönüşüm-imge' (change-image) olarak tanımladığı duruma vurgu yapan 'elma', ve 'cesedin yanına konulan kavunlar'; birer nesne olarak elma ve kavunun çok ötesine geçip Mitry'nin (1989: 91) imge oluşumunda 'rölyef' etkisinden söz ettiği bir açıışı olanaklı hale getirir. Benzer bir katmanlılık ve açılış, savcının (Taner Birsel) yakın plan yüz çekimlerinde de aynı izlenimi yaratır. Gizemini üstü kapalı bir şekilde, kendini bir 'öteki' konumuna yerleştirerek anlattığı ökü boyunca, teknik olarak gerek mimik ve makyaj, gerekse psikolojik bir derinlik yaratma anlamında bir film karakterinin yüzü; gölgeleri, eski yara izleriyle ruhun aşındırdığı kraterler gibi vurgulanır. Morin (2005: 69-70), 'Yüz Ruh'tur' (Face is Soul) başığında, "Ekranda yüz bir manzara haline, manzara da yüz haline gelir, işte bu da ruhtur" der.

'Bir Zamanlar Anadolu'da', karakterlerin iç dünyasından, toplumsal düzleme doğru genişleyerek açıır. Bu açılışı olanaklı kılan ise, yönetmen başta olmak üzere, öyü ve senarist olarak Ercan Kesal'ın, kamera yönetmeni olarak Gökhan Tiryaki'nin, ışık yönetiminin, oyunculuğun ve oyunculuk yönetiminin başarısıdır.

Bir kasabanın sıkıcılığı (bozkır atmosferi), boğuculuğu ve bu dolayımla anlam yaratması, sınırlı ve sıkışı bir mekân/mizansen izlenimini Türkiye'nin geneline taşıyan bir yorum sunar. Kısıtlanma, kıstırılma, aidiyet, an'ın ve şimdinin tasavvufi ve varoluşçu yansımaları, geleceksizlik, belirsizlik, suç ortaklığı ve benzeri zihinsel, duygusal ve geleneksel/ kültürel yansımalar 'Türkiye'nin bütününü ve 'kasabalılık hali'ni eşdeg̃er konuma getirir. Bu aşamada önemli olan bu vurgunun didaktik, sloganlarla ve kaba hatlarla işlenmeyip, sinemasal bir form olarak estetik, sanatsal ve sinema yoluyla üretilen bir felsefi boyutta iletilmesidir.

\section{Notlar}

$1 \quad$ 23.04.2012 tarihinde, 12. Uluslararası İzmir Film Festivali'nde bir master class gerçekleştiren Nuri Bilge Ceylan; 'Filmlerinizde politik eleştiri olmamasının bir nedeni var mı?' sorusuna cevap olarak; 'Herkes kendisini zorlayan meseleler üzerine film yapar. Güncellik daha çok gazetecilerin işidir. Örneḡin Dostoyevski'nin Ecinniler'i genel olarak dünyada yapılmış en iyi politik eserlerden biridir.' demiştir.

2 Doktor ve Arap Ali'nin diyaloguyla başlayan sahne, karakterlerden önce birine (önce Arap Ali'nin yüzüne) daha sonra diğerine (doktorun ensesine) zoom-in yaparak diyalogdan, monologa evrilir. Aslında birer iç konuşma gibi duran bu replikler sonunda yine diyalog gibi algılanır. Bu noktada batılı ve doğulu anlamda "varoluş" sorunsalına vurgu yapılır. "Arap Ali: Bizim buralarda böyle Doktor, kendi göbeğini kendin keseceksin. Ha yok ben kesemem arkadaş diyorsan iki dakikada alırlar çapını. Nereden geldiğini şaşırırsın. Yok işte öyle, hem şoför mahalli olsun, hem cam kenarı olsun, hem de bedava olsun, yemezler. 
Maalesef hayvan terli.." (Ali'nin yüzüne ağır ağır zoom-in yapılır) "Arap Ali: Adamın gözünden sürmeyi çekerler, üstüne üstlük bir de seni borçlu çıkarırlar. Onu bilir onu söylerim. Dairede oturacaksın, merkezi kollayacaksın. Ha, çember olsa olmaz mı? Olur, o da olur. Fakat, yerinde ve zamanında, Doktorun ensesine zoom-in yapılırken Arap Ali'nin iç sesi (dış ses) devam eder: “Arap Ali: Fakat icap ederse vazgeçmeyi de bileceksin. Hiç birimiz dünyaya kazık çakmadık değil mi Doktor? Hazreti Süleyman 750 yaşına kadar yaşamış, altın, mücevher, e dünya ona da kalmamış değil mi Doktor?" Buradan Doktor'un iç sesine geçilir: "Yine yağmur yağıyor, yağsın. Yüzyıllardır yağıyor. Ne fark eder? Fakat bundan sadece yüz yıl sonra ne sen, ne ben, ne savcı, ne komiser. Aynı şairin dediği gibi; yine yıllar geçecek ve geride benden bir iz kalmayacak. Yorgun ruhumu karanlık ve soğuk kuşatacak."

3 Gabriel Garcia Marquez' in 1981 yılında yazdığı, 1982 yılında Nobel Edebiyat Ödülü’ne layık görülen "Kırmızı Pazartesi”, işleneceğini herkesin bildiği bir cinayeti anlatır. Ancak cinayeti kimin işleyeceğini ve kimin öldürüleceğini herkes bilmekle birlikte kimse buna engel olmamaktadır. Roman bir cinayet oyküsü arka planında asıl olarak halkın ortak davranış biçimlerini ve iç yüzünü ortaya çıkarır. Basit bir namus cinayeti gibi durması sadece gerçekliğin en dış yüzeyinde kalır. Asıl mesele, topluluktan bir kişinin cinayeti önlemeye kalkışması durumunda topluluğu bir arada tutan bağların çözülmesi ve dağılması anlamına geleceği için hiç kimse böyle bir davranışa yeltenmez.

4 ; "Sergio Leone yalnızca filmin adına ilham vermiyor, filmin estetik duygusunda fazlasıyla western ruhu var." (Akdemir, 2011). “Ceylan'ın filmi, İtalyan yönetmen Sergio Leone'nin Bir Zamanlar Batı'da filmi gibi açılıp, ondan on altı yıl sonra çekilen Bir Zamanlar Amerika gibi bitiyor. Leone için son derece güçlü olan şey acıya, yalnız ya da ölmüş bir adama ya da kayıp zamana övgüdür. Ceylan, Leone'nin destansı manzaralarını ve kayıp zaman duygusunu benimseyip böylece bizimle karakteristik bir oyuna girişiyor." (Blincoe,2012).

5 Bu paragrafta aktarılan bilgiler, 23.04.2012 tarihinde gerçekleştirilen 12. Uluslararası İzmir Film Festivali'nde Nuri Bilge Ceylan Masterclass'ından alınmıştır.

6 Fort-da Oyunu, Freud'un "gitti-geldi" oyunu olarak tanımlanır. Çocuğun annesinin yokluğunu bastırmak için makarayla oynadığı bir tür oyundur. Buna göre, bebeğin simgesel düzen içinde kullandığı ilksel nesneler onun için küçük ötekilerdir (objet petit a). Oyun olarak fort-da (var-yok), bir nesnenin kaybolup belirmesidir. Böylece bebek eksik kavramını geliştirir ve bebeğe kendi tamamlanmamışlığını anımsatır. (Çoban, 2013)

\section{Kaynakça}

Atam, Zahit (2011). Yakın Plan Türkiye Sineması, İstanbul: Cadde Yayınları.

Bakhtin, Mikheal (2000). Karnavaldan Romana, çev. Cem Soydemir, İstanbul: Ayrıntı Yayınları.

Bergson, Henri (1950). Time and Free Will-an essay on the immediate data of consciousness, London. George \& Unwin Ltd.

Bilgin, Nuri (2005). Siyaset ve Insan, i̇stanbul: Bağlam Yayınları.

Bordwell, David (2010). Sanat Sineması Üzerine, der. Ali Karadoğan, Ankara: Deki Yayınları.

Canetti, Elias (1998). Kitle ve iktidar, çev. Gülşat Aygen, İstanbul: Ayrıntı Yayınları.

Eagleton, Terry (1990). Edebiyat Kuramı, çev. Esen Tarım, İstanbul: Ayrıntı Yayınları.

(1994). Eleştirinin Görevi, çev. İsmail Serin, İstanbul: Ark Yayınları.

Eco, Umberto (1994). Açık Yapıt, Çev. Yakup Şahan, İstanbul: Kabalcı Yayınları.

Freud, Sigmund (1989). Psikanaliz Üzerine, çev. A.Avni Öneş, Ankara: SayYayınları.

Gledhill, Christine (1987). "Mothering, Feminisim and Represantation", Home is Where the Heart is, ed. Christine Gledhill, London: PFI Publishing.

Mardin, Şerif (2002). Din ve İdeoloji, İstanbul: Iletişim Yayınları.

Marquez, Gabriel Garcia (1982). Kırmızı Pazartesi, çev. Faik Baysal, İstanbul:Can Yayınları.

Mauss, Marcel (2005). Sosyoloji ve Antropoloji, çev. Özcan Doğan, Ankara: Doğu-Batı Yayınları.

Mitry, Jean (1989). Sinema Estetiği ve Psikolojisi, çev. Oğuz Adanır, İzmir: DEÜ, GSF Yayınları.

Morin, Edgar (2005). The Cinema or the Imaginary Man, University of Minnesota Press.

Özkaya, Tüten (1977). “A.P.Çehov'un Oyunlarında Üslup Özellikleri”, Rus Edebiyatı Üzerine Yazılar, Ankar: San Matbaası.

Parla, Jale (2007). Don Kişot'tan Günümüze Roman, İstanbul: İletişim Yayınları.

Sizek, Slavoj (2002). Kırılgan Temas, çev. Tuncay Birkan, İstanbul: Metis Yayınları.

Totaro, Donata (1999). Gilles Deleuze's Bergsonian Film Project www.horschamp.qc.ca/9903/offscreen_essays/eleuze1.html (20.07.2011)

Ünlü, Aslıhan, (2009). Merkeze Dönmek, İstanbul: Mitos Boyut. 


\section{Internet Kaynakları}

Akdemir, Şenay (2011) “Ceylan'da Taşranın Otopsisi”, Radikal Gazetesi, 23.09.2011.

www.radikal.com.tr/sinema/ceylandan_tasranin otopsisi.1064134. erişim tarihi: 20.02.2012

Blincoe, Nicholas (2012). “Once Upon a Time in Turkey" 23.03.2012, www. majalla.com/eng/2012/03/article 55230134 erişim tarihi: 15.03.2013

Çoban, Barış. Lacan Aynalar Şövalyesi ya da Bilinçaltında Bir Seyyah www.academia.edu/608782 (25.02.2013) 